Nippon Suisan Gakkaishi $\quad \mathbf{5 6}(8), 1285-1292$ (1990)

\title{
ホシザメ筋肉の加熱ゲル化反応に及ぼす温度の影響
}

\author{
上西由翁, 御木英昌, 䃥端徹, 西元諪一
}

(1990 年 2 月 16 日受付)

\section{Effect of Temperature on Reactions of Heat-induced Gel Formation in Smooth Dogfish Muscle}

\author{
Yoshio Kaminishi, ${ }^{* 1}$ Hidemasa Miki, ${ }^{2}$ Tooru Isohata*2 \\ and Jun-ichi Nishimoto*2
}

\begin{abstract}
Effects of temperature on gel hardness of heat-induced meat paste gel and turbidity of myosin B solution prepared from shark muscle were investigated by applying to kinetics.

Their changes with time apparently proceeded to first-order reaction. The Arrhenius plots of their change rates for gel hardness and turbidity showed two straight lines with different slopes and indicated in the transition at 50 and $51^{\circ} \mathrm{C}$, respectively. On the other hand, the gel hardness changed little up to $40^{\circ} \mathrm{C}$ and then increased to $70^{\circ} \mathrm{C}$. The turbidity increased at $40-50^{\circ} \mathrm{C}$ and then decreased gradually on increasing the temperature. The typical network structure of heat-induced myosin B gel was observed above $50^{\circ} \mathrm{C}$ by scanning electron micrographs.

The results described above showed that the gel-forming reaction system of meat paste from smooth dogfish muscle during heating could be divided into two characteristic temperature ranges: below and above $50^{\circ} \mathrm{C}$. The aggregation reaction takes place below $50^{\circ} \mathrm{C}$ and the gelation reaction occurs above $50^{\circ} \mathrm{C}$.
\end{abstract}

がばこは，独特のデクスチャ一を有するため，その ゲル化機構に関して多くの研究がなされてきた。志水” は，多くの魚種のすり身からがぼこゲル形成性索調 ベ, $30 \sim 40^{\circ} \mathrm{C}$ 扣よび $60^{\circ} \mathrm{C}$ の 2 つ温度域に起こる坐 り，火戻り現象の有無别に加熱ゲル形成性を 4 タイブに 大別している。一方，かま仿このネットワーク棈築に関 与するミオシン B レペルでの研究では，ホシザメにつ

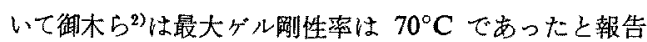
している。また, Sano ら ${ }^{8)} は$ 年温加熱による二イのミオ シン B の動的粘弾性から加熱ゲル化機構を 4 つの特致 的な温度带，つまり $32^{\circ} \mathrm{C}$ までの温度では弾性率にほと

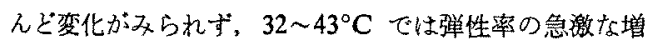
加上粘性率の著しい低下， $43 \sim 52^{\circ} \mathrm{C}$ て弾性率が著しく 低下するが 52 80 $\mathrm{C}$ で再び弾性率は増加する温度带に わけている。さらに, Ishioroshi ら,4 Samejima らは,

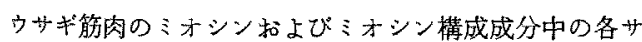
ブフラグントで加熱温度別に加熱ゲル翤性率和よび模 造变化を調べ，ミオシンには 2 つのゲル化反応が存在 し， $43^{\circ} \mathrm{C}$ でミオシン頭部の凝集反応および， $53 \sim 55^{\circ} \mathrm{C}$ 付近でミオシン尾部の架橋結合を述べている。このよう
に, 魚肉の肉糊や塩溶性タンパク質の加熱ゲル化に及ぼ す加熱の影響を調べるにあたっては，一定の加熱時間を 設けて加熱温度を变化させる方法や，帠温加熱による方 法などがー般に用いられてきたが，加熱温度と加熱時間 を相互に関連づけて述べた例は乏しい。

本実験では，上述のような加熱温度によるゲル化反応 をより理解するために，ホシザメを試料としてすり身の 加熱ゲル化に及ぼす温度の影響を速度論的観点から検討 した。また，加熱温度と加熱ゲルの構造をしるために，

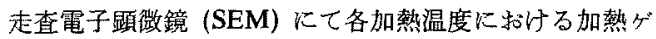
ルの微細構造について観察した。さらに，すり身ゲルの ネットワークを構成しているといわ机るオンンＢの 加熱中の挙動とゲル化過程との関連をみる一助として,

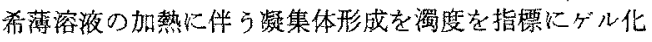
反応とあれせて加熱温度の影憼を検討した。

\section{実 験 方 法}

加熱ゲルの調慗およびゲル強度の測定 加熱ゲル試料 はホホシザメ Mustelus manazo（㕍览島県川内市沖で漁 獲）精肉索 10 倍量の水水にて水晒し啳, $0.2 \%$ ポリリン

*1 港坚岛大学大学院連合農学研究科 (The United Graduated School of Agricultural Science, Kagoshima University, Kagoshima 890 , Japan).

*2 垱児息大学水産学部 (Faculty of Fisheries, Kagoshima University, Kagoshima 890, Japan). 
酸，4\%ソルビット，4\%サッカロースを添加し，スピ 一ドカッター(ナショナル MK.K3 型) にて 2 分閐ホ モジナイズし得られたすり身を $-25^{\circ} \mathrm{C} て ゙$ 湅結後, 必要 な量だげを適宜取り出し流水解涷（1 h) して用いた。加 熱ゲルは，流水解涷したすり身に $3 \%$ N NaClを加え， 3 分閻ホモジナイズ後，得られた肉のり（水分含量 $80 \%$ ) を内法 $12 \times 12 \times 30 \mathrm{~mm}$ (厚さ $1 \mathrm{~mm}$ )のアルミ制ホルダ 一に棓め，所定の温度で所定の時間加熱後直ちに 10 分 間冷却し、ホルダーからゲルを取り出した。

加熱ゲルのゲル強度は，加熱ゲルを $12 \mathrm{~mm}$ 芒方のサ イズに成形した武料儿直径 $3 \mathrm{~mm}$ の円柱プランジャー 試料厭さの 8 制 $(12 \mathrm{~mm} \times 0.8=9.6 \mathrm{~mm})$ の深さまで押 し边九だをの罗大応力 $\left(\mathrm{g} / \mathrm{cm}^{2}\right)$ をレオナー(山筆 $\mathrm{RE}$ 3305 型)で検出して求めた。

ミオシン B の調製 ミオシン B は、ホシザメ精肉に ソルビットを $8 \%$ 混合してホモゲナイズし， $-25^{\circ} \mathrm{C}$ 保管したものを必要量たけ適宜流水解凍 $(1 \mathrm{~h})$ 後, 高 士き)の方法にしたがい調整した。加熱に用いたミオンン

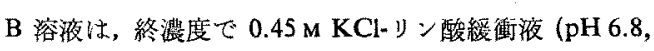
イオン強度 0.5) になる上らに調整し, 遠心分晟 $(20,000$ $\times \mathrm{g}$ ) 後，その上清区分である。オシンB 裖度は，ビ

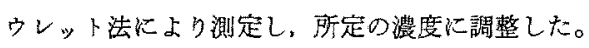

濁度の測定 濁度はガラス慜試験管 (内径 $11 \mathrm{~mm}$ ) に 濃度 $0.4 \mathrm{mg} / \mathrm{m} l$ のミオシン $\mathrm{B}$ 溶液 $2 \mathrm{ml}$ を分取し, 所 定の時間加熱, 10 分間冷却後, $350 \mathrm{~nm}$ に和ける吸光度 を測定した。なお、ミオンンＢの加熱前後におけるスペ
クトルより $350 \mathrm{~nm}$ 付近で濁度の極大変化がみられたの で，摆度の湘定波舆は $350 \mathrm{~nm}$ とした。

SEM による加熱ゲルの微細構造の観察 加熱ゲルは ミオンン B $(49.8 \mathrm{mg} / \mathrm{g})$ を $5 \mathrm{~mm}$ 角のホルダーK注入 し，所定の温度で 10 分間加熱・冷却したるのを用いた。 加熱ゲルを鋭利な內で約 $2 \times 2 \times 5 \mathrm{~mm}$ の大きさにトり ミングし，2.5\%-グルタルアルデヒド（20 mM-リン酸緩 衙液, $\mathrm{pH} 7.0)$ で 30 分間固定し, ピンセットで引き裂 、約 1 1.5 mm 角になるように成形した後，さら に同淮にて 1 次固定後, $1 \%$-四酸化才スミウム $(20 \mathrm{~mm}$ りン酸綬㜆液， pH 7.0) K上る二次固定を行った。固定 後の試料は, 濃度の異なるエタノール中で䫏次脱水後, ブチノールで置换し，凍結乾燥の後イオンスパッタリン グで金蒸着してから SEM (日本電子製 ISM-25 型) で 引き裂いた面の徽細棈造の観察を行った。

ゲル化および蜀度の变化速度 ゲル化扣よび濁度の变 化速度は，加熱過程の各加熱温度におけるゲル強度扰よ び濁度のそれぞれの最大值を $G_{\text {max }}, T_{\text {max }}$ ，初期值を $G_{0}$, $T_{0}$ とし, 反応速度式を適用して反応次数 $(n)$, 変化速度 を求めた。 $n$ については，1，3/2，2，叔よび 5/2 次につ いて検討したが，1 次であることがわかったので，両者 と見かけ上の 1 次反沈式を適用し，ゲル化速度定数 $\left(k_{6}\right)$ 㕲よび濁度の变化速度定数 $\left(k_{G}\right)$ を次式により求め た。

$$
\begin{aligned}
& k_{G}=1 / t \cdot \ln \left(\left(G_{\max }-G_{0}\right) /\left(G_{\max }-G_{t}\right)\right) \\
& k_{r}=1 / t \cdot \ln \left(\left(T_{\max }-T_{0}\right) /\left(T_{\max }-T_{t}\right)\right)
\end{aligned}
$$

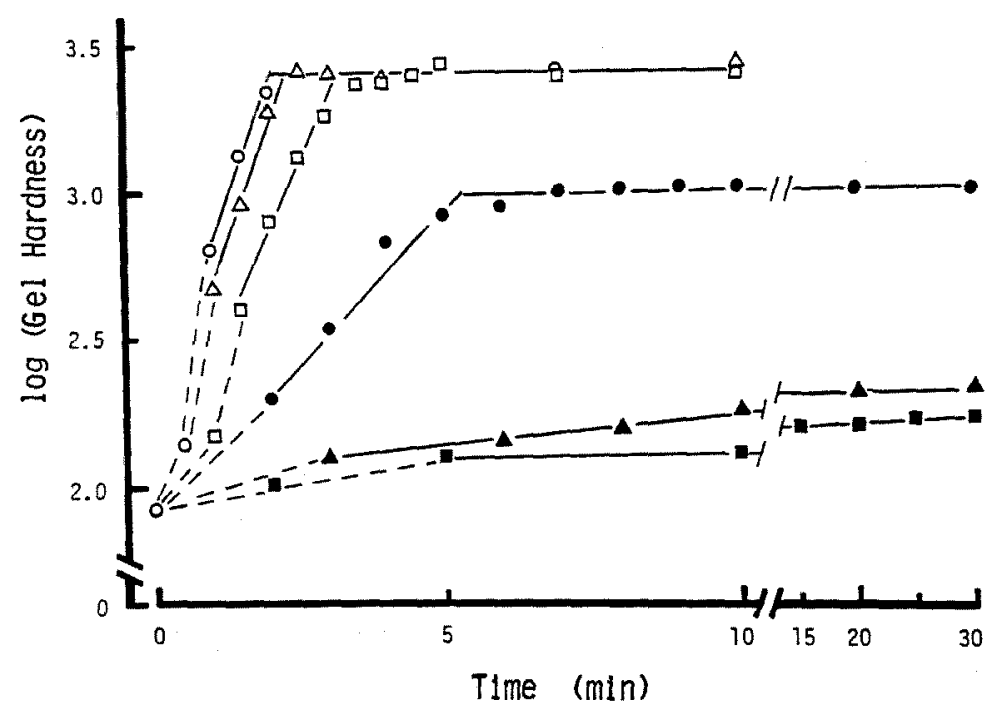

Fig. 1. Effect of heating time on gel hardness of heat-induced meat paste. Water content of meat paste was adjusted to $80 \%$.

घ: $30^{\circ} \mathrm{C}, 4: 40^{\circ} \mathrm{C}, 50^{\circ} \mathrm{C}$

ㅁ: $60^{\circ} \mathrm{C}, \triangle: 70^{\circ} \mathrm{C}, 0: 80^{\circ} \mathrm{C}$ 


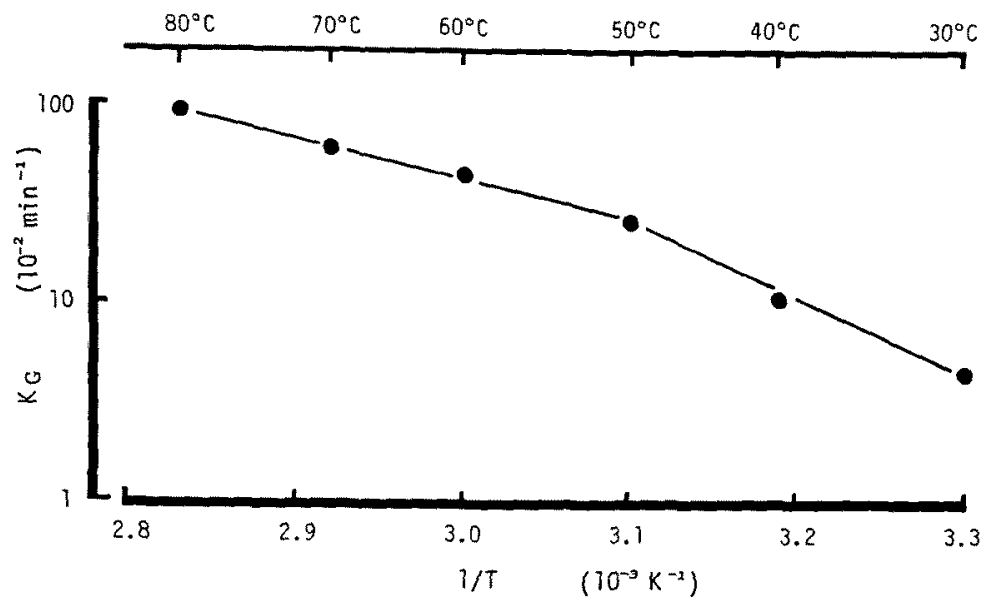

Fig. 2. Arrhenius plots of increasing rate of gel hardness obtained by heating meat paste at $30-80^{\circ} \mathrm{C}$.

また，各加熱温度に対する $K_{G}, k_{T}$ の Arrhenius plot の 直線の㑯 $(S)$ 加b, 次式にしたがってゲル化と濁度变 化について見かけ上の活性化エネルギ一(Ea) 求めた。

$$
E a=-2.303 \times R \times S
$$

ただし，Rは気体定数 $\left(1.987 \mathrm{cal} \cdot \mathrm{K}^{-1} \cdot \mathrm{mol}^{-1}\right)$ でる。

\section{結果および考察}

ホシザメすり身のゲル化速度に及はす温度の影響 各 加熱温度に和ける加熱時間に対寸るゲル强度の対数值の 変化をFig，1 K示した。ゲル強度は，30,40 $\mathrm{C}$ 加熱て

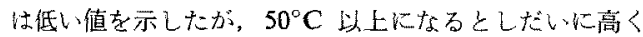

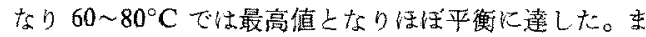
た，加熱時間に対するゲル強度の対数值は，ゲル強度が 平衡状態になる直前で一定の傾きをしつ洎線を示した。 $30,40^{\circ} \mathrm{C}$ で 90 分間まで加熱したが，そ礼でれ60分， 16 分以降に平衡状態に達した。それそれれの傾きは，低温 加熱ほど緩やかで高温になるはど大きくなった。さら に，加熱に上るゲル化反结の反应次数拈上び変化速度を 求婂たとる，見かけ上の一次区応にしたがった。各加 熱温度に括けるゲル化速度定数（見がのゲル化速度） は, Table 1 のらと加熱温度の上界に伴い高くなった。 ゲル化速度に及深す温度の影暗は, Arrhenius plot (Fig. 2) K示与上万以, $50^{\circ} \mathrm{C}$ 付近を転移温度とする2 の直線からなり，加熱 30〜50 $\mathrm{C}$ の低温側直線が $50 \sim$ $80^{\circ} \mathrm{C}$ の直線より6大きい㥧きを示した。な扰ボシザ メは坐りにくくて戻りにくい魚種〉をされているが，逆 の性質を有与るスケソウダラ泠涷すり身 (SA 級) に拈け る Arrhenius plot 他いててb、图示しないがホシザメと 同漛にこれらの転移温度は低温側に移り，傾きの買なる $2 つ の$ 線が示された。このよらに相反する性質の魚肉
Table 1. The apparent increasing rate for gel hardness of heat-induced meat paste

\begin{tabular}{cc}
$\begin{array}{c}\text { Temperature } \\
\left({ }^{\circ} \mathrm{C}\right)\end{array}$ & $\begin{array}{l}\text { Increasing rat of } \\
\text { gel hardness }\left(\mathrm{min}^{-1}\right)\end{array}$ \\
\hline 30 & 0.050 \\
40 & 0.104 \\
50 & 0.256 \\
60 & 0.436 \\
70 & 0.594 \\
80 & 0.897 \\
\hline
\end{tabular}

が同じよ5な2つの直線を示すことから，2つ0直線を 示古現象は坐りや㞔りに関保ない上考えられる。これら の直線の傾きから，无れぞれの見かけ上の $E a$ の值住， $30 \sim 50^{\circ} \mathrm{C}$ て $E a_{1}=15.9 \mathrm{kcal} / \mathrm{mol}, 50 \sim 80^{\circ} \mathrm{C}$ て $E a_{2}=$ $9.24 \mathrm{kcal} / \mathrm{mol}$ Cあり，Ea 任 $50^{\circ} \mathrm{C}$ 前後で低温側が約 1.7 倍と高い値を示した。

以上の上らに，異なる2 20 Ea 侹がみら机たこと

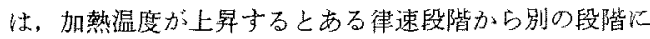
変化し，それによって $50^{\circ} \mathrm{C}$ 付近に転移温度》をもつ異 なる2つの反店系示したものであるら。Eaの值から

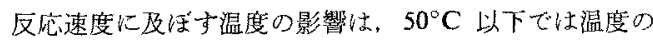
上开によりゲル化速度が著しく影製をらけるが，50 $\mathrm{C}$

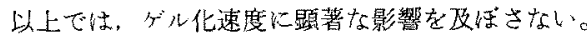

一方，各加熱温度とその最大ゲル强度との関係はFig. 3 の上らで, サ九筋肉から調整した肉糊の加熱がル強度

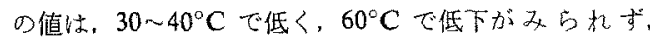
$70^{\circ} \mathrm{C}$ で最大值を示した。こ机志水のホシザィでの報

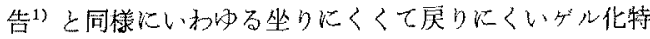
性であった。前報2でのホシザかミオシン B の 40

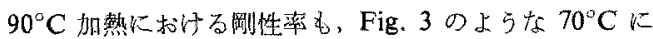




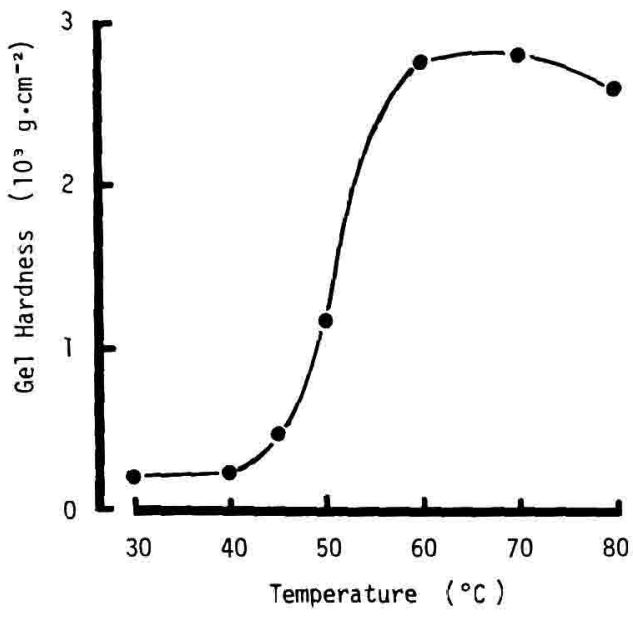

Fig. 3. Changes in a maximal gel hardness on heart-induced meat paste gel at a given temperature.

ピークをもつ京様の曲線を示すことから, 水晒し後の肉 糊の加熱ゲルはミオシン B がゲルの主体をなしている
ものと思われる。

加熱温度の異なるゲルの SEM による観察 加熱ゲル 化は $50^{\circ} \mathrm{C}$ を境にして2つの異なる反応系が存在してい たことより, 各加熱温度に扣ける微細棈造を SEM を用 いて観察した。ここでは試料にミオシン B を用いたが, それは水晒し後のすり身の加熱ゲル強度がミオンン $\mathrm{B}$ の 剛珄率と同様の傾向を示したこと，また，基質タンパク 質等の夾雑物を除さゲルの主体をなしているといわれる ミオンン B の微細構造を観察するためである。

SEM による網状構造 $(\times 7,500)$ は Fig. 4 に示す上う に $50^{\circ} \mathrm{C}$ 以上の温度から認められ, 加熱温度が高くなる

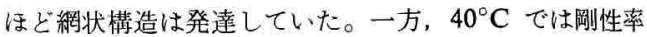
を測定できるよらなゲルを形成していたにもかかわら ず,網状構造はみられなかった。これは10,000 倍です網 状構造はみられなかった。ゲル化の定㼁をを “無限網状 高分子の生成”とすると7,500 倍の SEM 写真では $50^{\circ} \mathrm{C}$ がゲル化点として考えられた。

ミオシン $\mathrm{B}$ 溶液の加熱による濁度変化と凝固率との 関連 $50^{\circ} \mathrm{C}$ 以上で生成したゲルで従来いわれたように 網状構造が確認できたが， $40^{\circ} \mathrm{C}$ 以下では一応ゲル状態

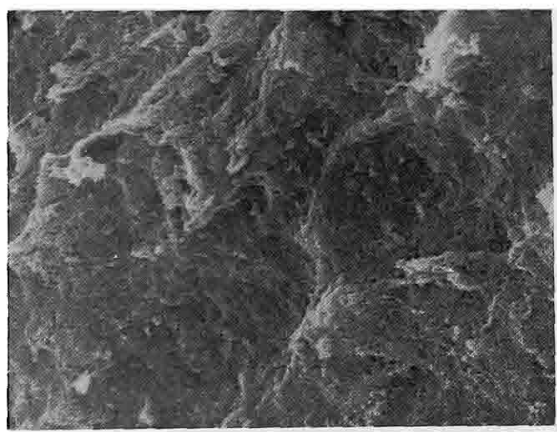

$40^{\circ} \mathrm{C}$

$-1 \mu \mathrm{m}$

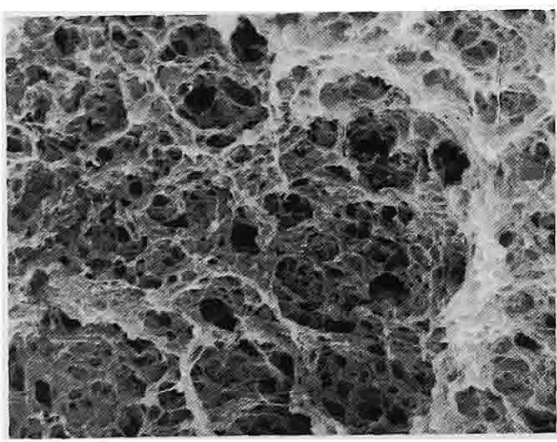

$60{ }^{\circ} \mathrm{C} \quad-1 \mu \mathrm{m}$

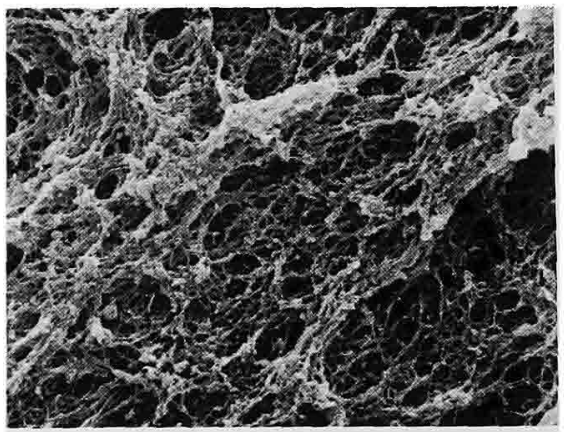

$50{ }^{\circ} \mathrm{C}$ $-1 \mu \mathrm{m}$

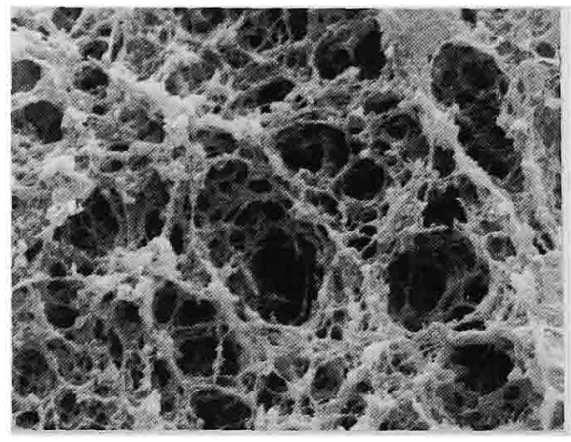

$70^{\circ} \mathrm{C} \quad-1 \mu \mathrm{m}$

Fig. 4. Scanning electron micrographs of heat- induced myosin $\mathbf{B}$ gel at each temperature for $10 \mathrm{~min} ;(\times 7,500)$. Protein concentration was $49.8 \mathrm{mg} / \mathrm{g}$. 


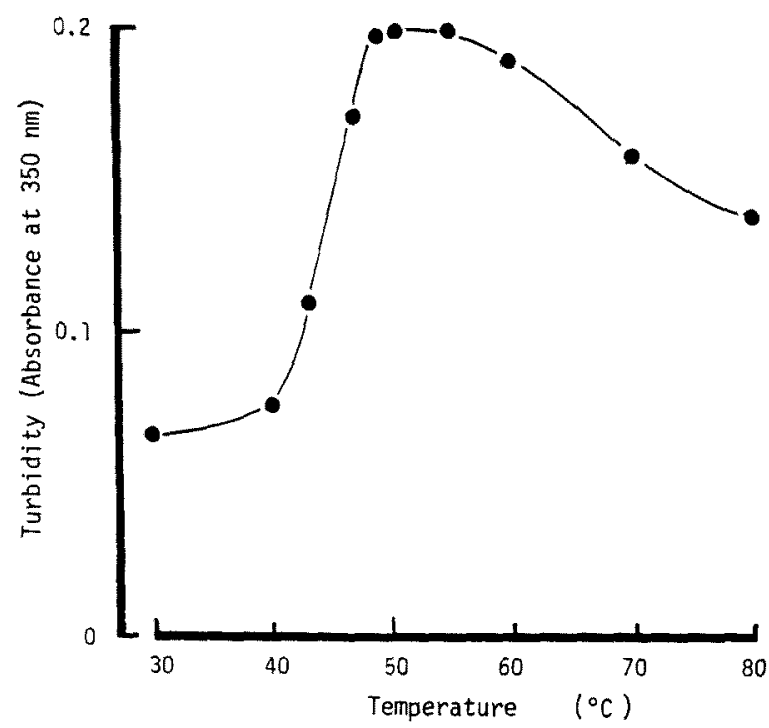

Fig. 5. Effect of temperature on the turbidity of heat-treated myosin B solution.

Myosin B solution $(0.4 \mathrm{mg} / \mathrm{ml})$ in medium containing $0.45 \mathrm{M} \mathrm{KCl}$ and $18.8 \mathrm{~mm}$ phosphate buffer ( $\mathrm{pH} 6.8$ ) was heated at a given temperature for $10 \mathrm{~min}$ and cooled at ice-water for $10 \mathrm{~min}$. The turbidity was determined by measuring at $350 \mathrm{~nm}$ in a spectrophotometer.

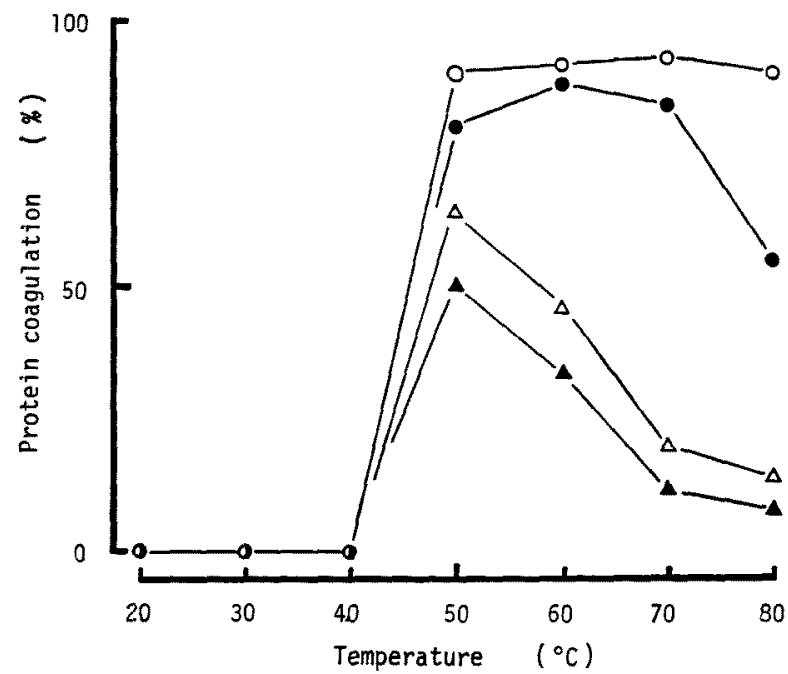

Fig. 6. Effect of myosin B concentration on coagulative rate by heating myosin $B$ solution at $30-80^{\circ} \mathrm{C}$ for $10 \mathrm{~min}$. After heat-treatment, myosin $\mathrm{B}$ was cooled in ice-water for $10 \mathrm{~min}$, and then centrifuged at $20,000 \times g$ for $15 \mathrm{~min}$. The coagulative rate was calculated from the equation, $\left(C_{s} / C_{o}\right) \times 100(\%)$, where $C_{o}$ and $C_{s}$ are the protein concentrations before and after centrifuging.

A: $0.4 \mathrm{mg} / \mathrm{ml}, \triangle: 1.0 \mathrm{mg} / \mathrm{ml}$

๑: $10.0 \mathrm{mg} / \mathrm{m} l, 0: 20.0 \mathrm{mg} / \mathrm{m} l$ 


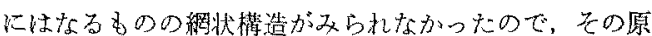
因解明の一つとしてタンパク筫の凝集性について検到し

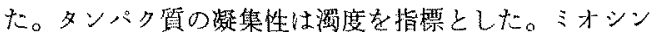

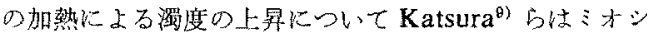
ン同土の凝集反応に依存していることを明らかにしてい るが、ミオシン B の加熱に上る濁度の上帠については

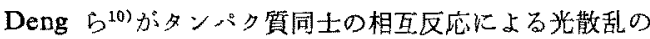
影響によって吸光度が增加することを述べていることか ら，濁度の上昇はミオンンと同様に㠜樂体形成を示唆す る束のと考觉られる。

本実鈳では，濁度の測定に際しタンパク筫濃度によ って沈澱を生ずるなどの濁度測定に支障があったので希 薄タンパ質溶液での濑度依存性について調べた。ミお シン $\mathrm{B}$ 濃度 0.1-1.0 $\mathrm{mg} / \mathrm{ml}$ の範国において，加熱前と 後 $\left(50^{\circ} \mathrm{C}\right)$ の濁度の変化はそれぞれ直線を示し $(r=0.999$, $n=7)$ ，このタンパク質濃度範用においては，加熱後の渴 度の測定值に急激な变動はみられなかった。 $50^{\circ} \mathrm{C}$ 以外 に $45,60^{\circ} \mathrm{C}$ でる同様であった。したがって，0.4 $\mathrm{mg} / \mathrm{ml}$

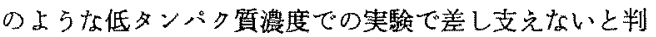
断し、このタンパク謴濃度において各加熱温度て，10分 間加熱したときの濁度を測定した（Fig．5)。濁度は，40

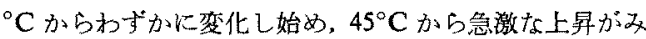

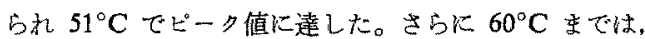

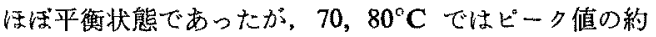
1/2 まで減少した。このビーク值 $\left(51^{\circ} \mathrm{C}\right)$ は，中山ら が hen meat のミオシン Bで行った結果 $\left(60^{\circ} \mathrm{C}\right)$ より かなりずれていたが，供試陚料の相違によるるのである
と思加れた。このように，濁度に及防す温度の影響は

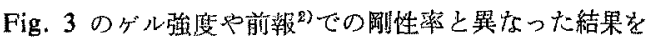
示し，濁度形成とゲル形成はそれでれ異なる反応である と思加れ。

濁度として測定される凝集体形成は“溶液中心分散し ていたものが集合して塊をつくる現象”であるから，濁 度と凝集体形成生との関係は加熱後のミォシン B D遠 心分離によって生しる沈搌の量、心わゆる凝固率と摆度 との関連になろう。その結果は，Fig. 6 K示すよ5に, ミオシン B 濃度が高い場合、 $50^{\circ} \mathrm{C}$ 以上の加熱では，そ

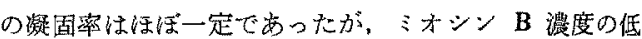
下にしたがって $50^{\circ} \mathrm{C}$ 以上に打ける凝固率は減少した。 また，タンパク質源度が低下するにしたがい各加熱温度

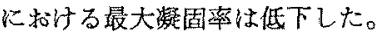

いずれにしてる，ホシザメに和いて性：ホオンＢ溶

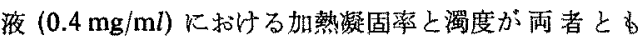
$50^{\circ} \mathrm{C}$ 付近にピーク持らその後低下するといら同し傾 间を示すことから，濁度と㠜固率とは密接な関係がある あのと考えられ，ミオンン B の凝集性に及ぼす加熱温 度の影響索速度論的に解析した。

濁度の变化速度に及ばす温度の影響 濁度を $40-60^{\circ} \mathrm{C}$ て経時的に測定し，その結果を Fig. 7 に示した。加熱 は 40-60 $\mathrm{C}$ の間で 8 点の温度で澌定したが，図には 4 点 $\left(40,44,47,60^{\circ} \mathrm{C}\right)$ のみを表示した。罢度はいずれの 温度でる時間ととるに上昇したが，上杽の割合や最大值 は加熱温度により相違しだ。

これらの結果から、濁度の変化逨度は見かけ上の1次

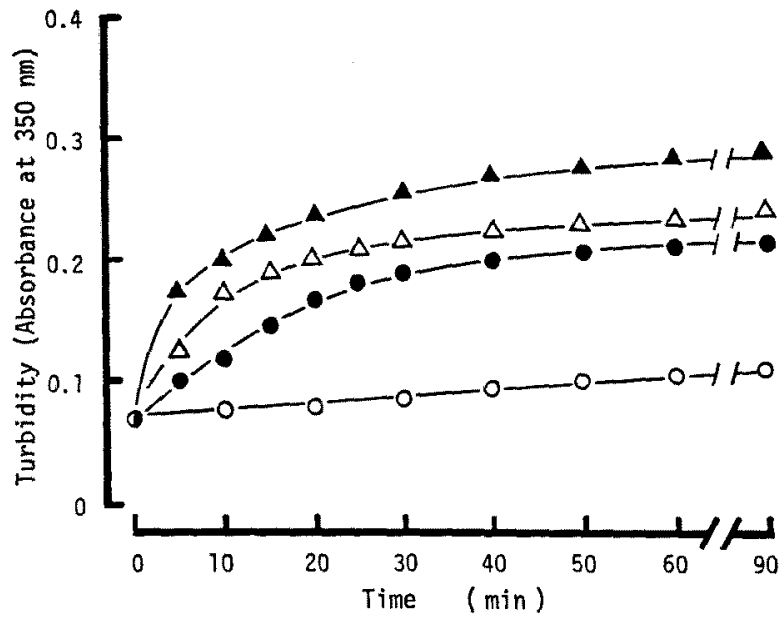

Fig. 7. Effect of heating time on the turbidity of myosin B solution $(0.4 \mathrm{mg} / \mathrm{ml})$. The turbidity was measured under the conditions shown in Fig. 5.

O: $40^{\circ} \mathrm{C}, 0: 44^{\circ} \mathrm{C}$

$\triangle: 47^{\circ} \mathrm{C}, \triangle: 60^{\circ} \mathrm{C}$ 


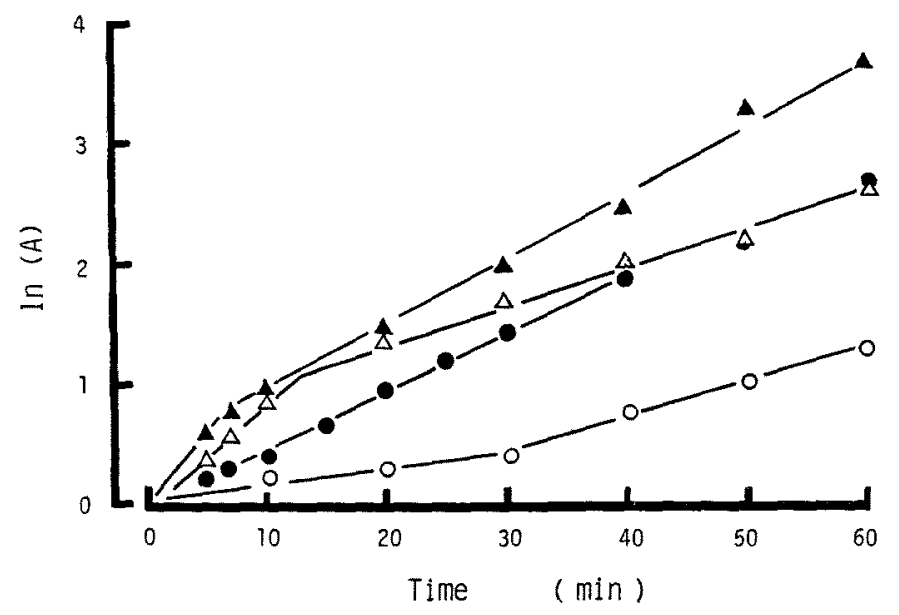

Fig. 8. Effect of heating time on turbidity of myosin $B$ solution $(0.4 \mathrm{mg} / \mathrm{ml})$.

The extent of the turbidity change (A) was calculated by using the relationship: $A=\left(T_{\max }-T_{0}\right) /\left(T_{\max }-T_{t}\right)$, where $T_{0}$ and $T_{t}$ are the turbidity values before and after $t$ minutes of heat-treatment. $T_{\max }$ is the maximal turbidity values at a given temperature.

O: $40^{\circ} \mathrm{C}, 0: 44^{\circ} \mathrm{C}$

$\triangle: 47^{\circ} \mathrm{C}, \triangle: 60^{\circ} \mathrm{C}$

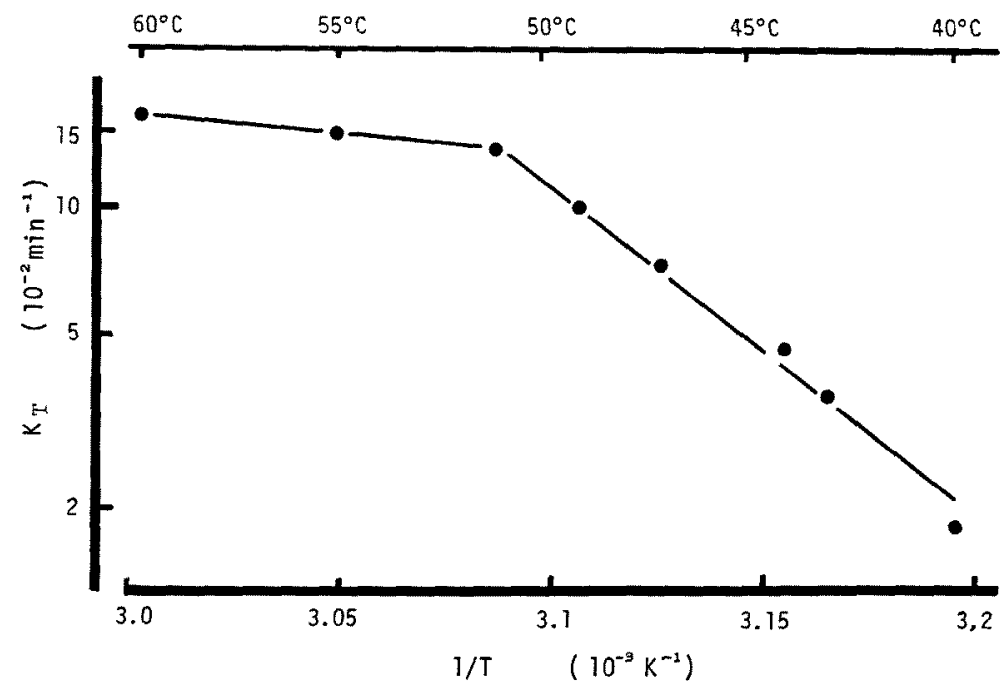

Fig. 9. Arrhenius plots of increasing rate of the turbidity obtained by heating myosin $B$ solution at $40-60^{\circ} \mathrm{C}$.

反応にしたがっており，Fig. 8 に亦すよらに，いずれの 加熱温度でる初期反応と後期反応の 2 つ直楾が示さ れ，40ㄷ では初期に幄く後期に速い反底であり，43$60^{\circ} \mathrm{C}$ の間では初期に速く啳期に漣い反応であった。 mura $^{12)}$ らは，カッオとウサギのミオシンの加熱による 溜度の変化速度加，初期に速く後期に荤い2

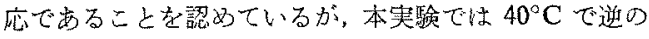
結果が得られた。この理由は不明である。激度の変化速 度は Table 2 のらに加熱温度が上昇するにしたがって 高い值を示した。また，各加熱温度の初期反応における 蠋度の変化速度の Arrhenius plot は Fig. 9 に示したよ うに, ゲル化の場合と同様に2つの直線からなって打 
Table 2. The apparent increasing rate for the turbidity of heat-treated myosin B solution.

\begin{tabular}{cc}
\hline $\begin{array}{c}\text { Temperature } \\
\left({ }^{\circ} \mathrm{C}\right)\end{array}$ & $\begin{array}{c}\text { Increasing rate of } \\
\text { turbidity }\left(\mathrm{min}^{-1}\right)\end{array}$ \\
\hline 40 & 0.017 \\
43 & 0.036 \\
44 & 0.045 \\
47 & 0.073 \\
49 & 0.100 \\
51 & 0.137 \\
55 & 0.149 \\
60 & 0.163 \\
\hline
\end{tabular}

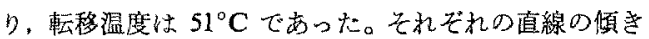
から 40-51 ${ }^{\circ} \mathrm{C}$ の間で $E a_{1}=37.05 \mathrm{kcal} / \mathrm{mol}, 51-60^{\circ} \mathrm{C}$ の 間で $E a_{2}=4.125 \mathrm{kcal} / \mathrm{mol}$ と見かけ上の $E a$ が算出さ れ，このようにミォシン B 孛用いた濁度についてbゲ 儿强度之同様に $50^{\circ} \mathrm{C}$ 付近枟移温度を子つ2 つ0反 応系の存在が考无られた。

澄度の変化肪ミオシン B 同士の相互作用による凝策 性を示したこと，Fig. 5 上り濁度の上留が $40^{\circ} \mathrm{C}$ から $50^{\circ} \mathrm{C}$ だでみられたことなどを考光ると２２0反応 系での $50^{\circ} \mathrm{C}$ 以下では㵀集反応が起こっているすのと思 われた。

以上よりゲル化反応に及洼す温度の影響を試料魚に ホシザメを用い加熱ゲル㤝度を指標に速度論的観点から 検討した結果， $50^{\circ} \mathrm{C}$ 付近を境にした温度域で見かけ上 の活性化エネルギーの異なる2つの反広手が存在してい

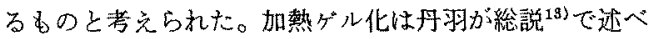
ている上らに多様な結合からなっており，単に1つの反 矿たけに依存しない椱雑な反忘形熊をるっているるのて

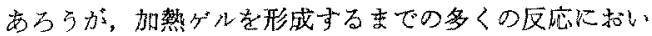
ては，加熱温度が $50^{\circ} \mathrm{C}$ なである律速段階から、50 以上の加熱火よって别の段階に变化し，无のために

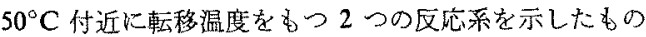
と思われた。さらに，SEMによる微細椿造の観察上り， $50^{\circ} \mathrm{C}$ 以上では絧状棈造の発達が認められたが，50 $\mathrm{C}$ 以

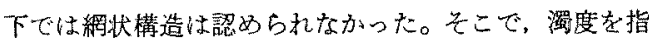

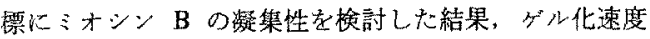

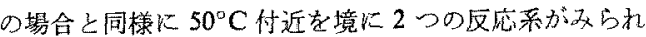

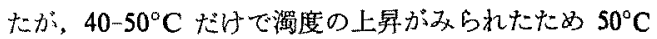
出でのダル懝集反応によると思われた。したがって，

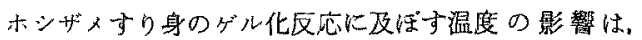
SEM による維状棈造の形成が確認されたことより $50^{\circ} \mathrm{C}$ 以上の温度ではダル化反忘，罢度の結果より $50^{\circ} \mathrm{C}$ 以下では凝集反応であるらと推察さ机た。

終加りに，走查電子揭徽鏡写真撮影に便宜や御助言を

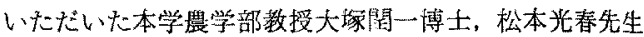
に衔礼申し上げす。

\section{文献}

1) 志水 筧, 町田 律，竹並䠞一：日水誌，47, 95-104 (1981).

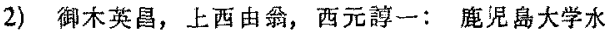
座学部紀要, 37, 35-43 (1988).

3) T. Sano, S. F. Noguchi, T. Tsuchiya, and J. J. Matsumoto: J. Food Sci., 53, 924-928 (1988).

4) M. Ishioroshi, K. Samejima, and T. Yasui: J. Food Sci., 44, 1280-1284 (1979).

5) K. Samejima, M. Ishioroshi, and T. Yasui: J. Food Sci., 46, 1412-1418 (1981).

6) 高士合二，新井健一，齐藤恒行：日水嘉，36， 169-172 (1970).

7) I. H. Segel: シーゲル生化学計算法（永井裕， 石倉久之，林 利彦訳)，虚川書店，東京，1979， pp. 312-314.

8）「高分子科学の基碳」䄽集委員会：高分子科学の 基礎（高分子学会編），東京化学同人，東京， 1988 , pp. $250-252$.

9) I. Katsura and H. Noda: J. Biochem., 69, 219-229 (1971).

10) J. Deng, R. T. Toledo, and D. A. Lillard: J. Food Sci., 41, 273-277 (1976).

11) T. Nakayama and Y. Sato: J. Texture Studies, 2, 475-488 (1971).

12) I. Kimura, K. Arai, K. Takahashi, and S. Watanabe: J. Biochem., 88, 1703-1713 (1980).

13) 丹羽栄二: 水産极り製品技術研究会誌, 7, 241251 (1981). 